\title{
Patterns of Cancer Genetic Testing: A Randomized Survey of Oregon Clinicians
}

\author{
Summer L. Cox, ${ }^{1}$ Amy I. Zlot, ${ }^{1}$ Kerry Silvey,,${ }^{1,2}$ Debi Elliott, ${ }^{3}$ Tara Horn, ${ }^{3}$ \\ Amber Johnson, ${ }^{3}$ and Richard F. Leman ${ }^{4}$ \\ ${ }^{1}$ Oregon Genetics Program, Public Health Division, Oregon Health Authority, Portland, OR 97232, USA \\ ${ }^{2}$ Oregon Center for Children and Youth with Special Health Needs, Child Development and Rehabilitation Center, \\ Oregon Health \& Science University, Portland, OR 97239, USA \\ ${ }^{3}$ Survey Research Lab, Office of Research and Sponsored Projects, Portland State University, Portland, OR 97201, USA \\ ${ }^{4}$ Center for Public Health Practice, Public Health Division, Oregon Health Authority, Portland, OR 97232, USA
}

Correspondence should be addressed to Summer L. Cox, summer.l.cox@state.or.us

Received 16 March 2012; Revised 11 June 2012; Accepted 12 June 2012

Academic Editor: Suzanne C. O’Neill

Copyright (C) 2012 Summer L. Cox et al. This is an open access article distributed under the Creative Commons Attribution License, which permits unrestricted use, distribution, and reproduction in any medium, provided the original work is properly cited.

\begin{abstract}
Introduction. Appropriate use of genetic tests for population-based cancer screening, diagnosis of inherited cancers, and guidance of cancer treatment can improve health outcomes. We investigated clinicians' use and knowledge of eight breast, ovarian, and colorectal cancer genetic tests. Methods. We conducted a randomized survey of 2,191 Oregon providers, asking about their experience with fecal DNA, OncoVue, BRCA, MMR, CYP2D6, tumor gene expression profiling, UGT1A1, and KRAS. Results. Clinicians reported low confidence in their knowledge of medical genetics; most confident were OB-GYNs and specialists. Clinicians were more likely to have ordered/recommended BRCA and MMR than the other tests, and OB-GYNs were twice as likely to have ordered/recommended $B R C A$ testing than primary care providers. Less than $10 \%$ of providers ordered/recommended OncoVue, fecal DNA, CYP2D6, or UGT1A1; less than 30\% ordered/recommended tumor gene expression profiles or KRAS. The most common reason for not ordering/recommending these tests was lack of familiarity. Conclusions. Use of appropriate, evidencebased testing can help reduce incidence and mortality of certain cancers, but these tests need to be better integrated into clinical practice. Continued evaluation of emerging technologies, dissemination of findings, and an increase in provider confidence and knowledge are necessary to achieve this end.
\end{abstract}

\section{Introduction}

Genomic medicine has entered the clinical setting. Currently available genomic ${ }^{1}$ and genetic tests enable disease surveillance and individually tailored treatment, and many more such tests are on the horizon. Chronic diseases, including breast, ovarian, and colorectal cancer, have multifactorial etiologies, including genetic components. In 2010, breast and colorectal cancer were among the four most commonly diagnosed cancers and were the second and third most common causes of cancer death in both the USA and in Oregon [1]. An estimated 5\%-10\% of all breast and ovarian cancers are hereditary, meaning a single gene mutation contributed to development of the cancer. The majority of these inherited cancer cases are due to mutations in breast cancer susceptibility genes, which include $B R C A 1$ and $B R C A 2$ (BRCA) [2]. Women within the general population have a $12 \%$ lifetime risk of developing breast cancer and a $1 \%$ lifetime risk of developing ovarian cancer [3]. For women with BRCA mutations, however, the lifetime cancer risk is greater. It is estimated that $47 \%-66 \%$ of women with BRCA1 mutations will develop breast cancer by age 70 , while $35 \%-46 \%$ of them will develop ovarian cancer by that age [4]. Risk of developing certain other cancers (e.g., pancreatic cancer) also increases markedly. Currently, identified mutations account for 5\%-6\% of colorectal cancer cases [5]. The general population has a $6 \%$ lifetime risk of developing colorectal cancer, but for those with mismatch 
repair gene $(M M R)$ mutations, the risk increases to $80 \%$, and the risk of developing certain other cancers (e.g., endometrial cancer) also increases substantially [6]. Morbidity from these heritable mutations places a substantial burden on both those who have them and on the health care system.

Genetic tests that can be used for population-based cancer screening, diagnosis of inherited cancer syndromes, and selection of specific cancer therapies most likely to be effective for a given patient are now commercially available [7-15]. In order to take full advantage of valid and clinically useful genetic tests, health care providers must not only become aware of them, but also become knowledgeable about their use and interpretation. Providers must continue to improve their skills in assessing family history and other relevant factors to stratify patient risk for specific cancers, improve decision making for referral to genetic specialists ${ }^{2}$, and decide when consideration of genetic testing is appropriate for a given patient [16-23]. The increased use of direct-to-consumer marketing for cancer-related genetic tests makes this doubly important, as clinicians are increasingly called upon to interpret the results of a genetic test that may have been ordered directly by their patient rather than a health care provider.

In the current health care milieu, providers in many different settings can order or recommend a genetic test. Physicians or midlevel providers such as physician assistants and nurse practitioners can order these tests in a primary care setting, alternate or complementary care providers such as naturopaths may order them, and specialists who primarily see patients with cancer may order these tests as well. The familiarity of these different provider groups with such tests, their patterns in ordering them, and their confidence in interpreting them may differ.

Our survey evaluated the extent to which health care providers in different practice settings use eight commercially available genetic tests to assess personal or familial risk for breast, ovarian, and colorectal cancer, or to guide treatment for these conditions. We also explored providers' rationale for ordering/recommending these tests, their reasons for not ordering/recommending these tests if they refrain from doing so, their level of confidence in their knowledge of medical genetics, and whether they refer to genetic specialists. The genetic tests we evaluated fall into three categories: (1) population-based cancer screening, (2) refined risk assessment for specific cancers in patients already identified as high risk due to family or personal history, and (3) testing to guide cancer treatment decisions.

In our study, we surveyed provider use of fecal DNA, OncoVue, BRCA, MMR, CYP2D6, breast cancer tumor gene expression profiling, UGT1A1, and KRAS testing. Table 1 lists each of the tests, describes them, and summarizes the evidence-based recommendations published by the Evaluation of Genomic Applications in Practice and Prevention (EGAPP), the U.S. Preventive Services Task Force (USPSTF), and the National Comprehensive Cancer Network (NCCN). The evidence regarding the clinical utility and potential harms associated with these tests continues to grow. Guidelines for these tests range from recommending use of the test in specific circumstances, to concluding there is insufficient evidence to recommend for or against using the test, to recommending against use of the test. The recommendations conflict for some tests. It is important for clinicians to understand both the benefits and limitations of testing and be aware of the importance of pre- and posttest counseling. A better understanding of how, and why, health care providers use cancer genetic tests can inform policy development and educational efforts to ensure the appropriate and effective use of these tests.

\section{Methods}

2.1. Study Population. The Oregon Genetics Program conducted the 2010 Oregon Health Care Provider Survey in collaboration with the Portland State University Survey Research Lab. We generated a stratified random sample of primary care providers and specialists practicing in Oregon to evaluate the use of eight genetic tests for breast, ovarian, and colorectal cancer. We used the 2010 licensee databases from the Oregon Medical Board, the Oregon Board of Naturopathic Examiners, and the Oregon State Board of Nursing to identify possible respondents. Because the boards vary in their levels of specificity for practice specialty, in order to survey subspecialists who treat cancer, for example, breast surgeons, we sent surveys to some providers who are unlikely to screen or treat for breast, ovarian, or colorectal cancer, for example, head and neck surgeons. To target our study to providers who screen or treat for breast, ovarian, and colorectal cancer, we asked clinicians whether they recommended screening or treated for breast, ovarian, or colorectal cancer in both a screening postcard and on the survey. We excluded any respondent who reported neither recommending screening nor treating breast, ovarian, or colorectal cancer. We also asked clinicians to self-identify their specialty on the survey and removed surveys from the analysis if the responding clinicians indicated that they did not belong to one of the health care provider groups of interest.

We stratified the potential respondents into four provider groups: primary care providers, naturopaths ${ }^{3}$ obstetricians/gynecologists (OB-GYNs), and specialists. Primary Care Providers consisted of family physicians, internal medicine physicians, primary care (general practice, family medicine, or family practice) nurse practitioners, and primary care physician assistants. We analyzed Naturopaths separately to assess patterns of care among this growing class of alternate/complementary care providers. While one might consider obstetrics/gynecology a primary care specialty, we developed a separate stratum for this group because of the frequency with which they evaluate patients for possible ovarian or breast cancer. Specialists consisted of surgeons, colorectal surgeons, general surgeons, gastroenterologists, oncologists, and gynecologic oncologists.

2.2. Survey Instrument. A questionnaire was developed, piloted, and mailed to 2,506 Oregon health care providers in 2010. We sent up to three mailings to recipients. The first mailing included a prenotification letter with endorsements 
TABle 1: National guidelines for cancer genetic tests included in the 2010 Oregon Health Care Provider Survey.

\begin{tabular}{|c|c|c|}
\hline Test & Description & Recommendation \\
\hline \multicolumn{3}{|c|}{ Population-based screening for specific cancers } \\
\hline OncoVue & $\begin{array}{l}\text { Tests for single nucleotide polymorphisms associated with } \\
\text { increased breast cancer risk. }\end{array}$ & No recommendations from EGAPP, NCCN, or USPSTF. \\
\hline Fecal DNA & $\begin{array}{l}\text { Test designed to screen for colorectal cancer, has better } \\
\text { sensitivity than the traditional fecal occult blood test } \\
\text { (FOBT), and may be more acceptable to the public than } \\
\text { colonoscopy. }\end{array}$ & $\begin{array}{l}\text { (i) NCCN considers use of fecal (stool) DNA testing to be } \\
\text { an option, but does not recommend it as a "first-line" } \\
\text { screening tool [7]. } \\
\text { (ii) USPSTF found insufficient evidence to recommend } \\
\text { use of fecal DNA testing as a screening method for } \\
\text { colorectal cancer [14]. }\end{array}$ \\
\hline \multicolumn{3}{|c|}{ Further assessing risk for developing specific cancers in previously identified high-risk populations } \\
\hline$B R C A$ & $\begin{array}{l}\text { Tests designed to detect specific } B R C A \text { mutations } \\
\text { associated with increased risk for breast and ovarian } \\
\text { cancers. Providers use results to guide breast and related } \\
\text { cancer prevention efforts. }\end{array}$ & $\begin{array}{l}\text { (i) NCCN and USPSTF recommend } B R C A \text { testing for } \\
\text { patients at increased risk of developing breast and/or } \\
\text { ovarian cancer due to family history }[8,14] \text {. }\end{array}$ \\
\hline$M M R$ & $\begin{array}{l}\text { Testing for Lynch syndrome (previously known as } \\
\text { HNPCC) includes testing of one or all of the most } \\
\text { common mismatch repair genes }(M M R)-M C H 1, M S H 2 \text {, } \\
\text { MSH6, and PMS2. Providers use results to guide cancer } \\
\text { prevention efforts. }\end{array}$ & $\begin{array}{l}\text { (i) EGAPP recommends genetic testing for Lynch } \\
\text { syndrome in individuals with newly diagnosed colorectal } \\
\text { cancer to reduce morbidity and mortality in relatives. } \\
\text { They found insufficient evidence to recommend a specific } \\
\text { testing strategy [11]. } \\
\text { (ii) NCCN recommends testing for Lynch syndrome for } \\
\text { individuals who meet certain criteria. The testing strategy } \\
\text { will depend on whether there is a known } M M R \text { mutation } \\
\text { in the family [7]. }\end{array}$ \\
\hline
\end{tabular}

Guiding cancer treatment decisions in those already diagnosed with cancer

\begin{tabular}{|c|c|c|}
\hline$B R C A$ & $\begin{array}{l}\text { Test designed to detect specific } B R C A \text { mutations } \\
\text { associated with increased risk of aggressive, recurrent } \\
\text { cancers. Providers use results to guide treatment decisions } \\
\text { for people with breast, ovarian, and related cancers. }\end{array}$ & $\begin{array}{l}\text { (i) NCCN recommends } B R C A \text { testing when the patient } \\
\text { meets certain personal and family breast and/or ovarian } \\
\text { cancer history criteria }[8] \text {. }\end{array}$ \\
\hline $\begin{array}{l}\text { Tumor gene } \\
\text { expression } \\
\text { profiles }\end{array}$ & $\begin{array}{l}\text { Three tests, Oncotype DX, MammaPrint, and H/I ratio, } \\
\text { are currently being marketed to help women with breast } \\
\text { cancer and their providers make treatment decisions and } \\
\text { estimate risk of cancer recurrence. }\end{array}$ & $\begin{array}{l}\text { (i) EGAPP found insufficient evidence to advise for or } \\
\text { against the use of tumor gene expression profiles in } \\
\text { women with breast cancer [12]. }\end{array}$ \\
\hline CYP2D6 & $\begin{array}{l}\text { Test designed to help determine whether tamoxifen is } \\
\text { likely to be a useful therapy in those with estrogen } \\
\text { receptor-positive breast cancer. }\end{array}$ & $\begin{array}{l}\text { (i) No recommendations from EGAPP, NCCN, or } \\
\text { USPSTF. }\end{array}$ \\
\hline$M M R$ & $\begin{array}{l}\text { Testing for Lynch Syndrome (previously known as } \\
\text { HNPCC) includes testing of one or all of the most } \\
\text { common mismatch repair genes }(M M R)-M C H 1, M S H 2 \text {, } \\
\text { MSH6 and PMS } 2 \text {. Providers use the results to guide cancer } \\
\text { management efforts. }\end{array}$ & $\begin{array}{l}\text { (i) EGAPP recommends genetic testing for Lynch } \\
\text { syndrome in individuals with newly diagnosed colorectal } \\
\text { cancer. They found insufficient evidence to recommend a } \\
\text { specific testing strategy [11]. } \\
\text { (ii) NCCN recommends testing for Lynch syndrome for } \\
\text { individuals who meet certain criteria }{ }^{\mathrm{h}} \text {. }\end{array}$ \\
\hline$U G T 1 A 1$ & $\begin{array}{l}\text { Test designed to help identify colorectal cancer patients } \\
\text { who are at increased risk for an adverse reaction to } \\
\text { irinotecan therapy and allow for changes in management } \\
\text { (e.g., drug choice, dosage). }\end{array}$ & $\begin{array}{l}\text { (i) EGAPP found insufficient evidence to recommend use } \\
\text { of } U G T 1 A 1 \text { genotyping in patients with metastatic } \\
\text { colorectal cancer treated with irinotecan }[10] \text {. }\end{array}$ \\
\hline KRAS & $\begin{array}{l}\text { Testing for KRAS gene mutations may help identify } \\
\text { colorectal cancer patients who may not respond well to } \\
\text { EGFR-inhibiting drugs such as panitumumab (Vectibix) } \\
\text { and cetuximab (Erbitux). }\end{array}$ & $\begin{array}{l}\text { (i) NCCN recommends testing for KRAS tumor gene } \\
\text { status in patients with metastatic colorectal cancer before } \\
\text { initiating treatment with panitumumab or cetuximab } \\
{[24] \text {. }}\end{array}$ \\
\hline
\end{tabular}

from leaders from each practice group surveyed and a postage-paid screening postcard. The postcard asked if the clinician recommended screening or treated breast, ovarian, or colorectal cancer; we removed respondents who returned the postcard as ineligible from the mailing survey. The survey was sent in the second mailing via priority mail with a \$10 cash incentive, postage-paid return envelope, cover letter including an electronic link of the survey (so clinicians could respond either electronically or in written form), and the endorsement letter. We did not send this second mailing to respondents who had already responded online; we sent those respondents a check for \$10 separately. 
In the third mailing, we sent a postcard to nonresponders with a link to the web-based survey. We made follow-up phone calls to nonresponders from both the first and the second round of survey mailings. In the survey, we asked questions about provider demographics, length of time in practice, practice setting, the provider's level of confidence in their knowledge of medical genetics, referral to genetic specialists, and use of family history to assess risk for breast, ovarian, and colorectal cancer. Portland State University Human Subjects Research Review Committee approved the survey, the informed consent process and the data collection protocol.

2.3. Survey Measures. We determined whether to ask a clinician about a particular test by the clinician's answers to four questions. (1) Providers who answered "yes" to the question, "In your practice, do you recommend breast and/or ovarian cancer SCREENING to patients without cancer?" were asked about OncoVue and BRCA testing. (2) Providers who answered "yes" to the question, "In your practice, do you recommend colorectal cancer SCREENING to patients without cancer?" were asked about fecal DNA and Lynch Syndrome genetic testing. (3) Providers who answered "yes" to "Do you TREAT patients for breast and/or ovarian cancer?" were asked about BRCA, breast cancer tumor gene expression profile, and CYP2D6 testing. (4) Providers who answered "yes" to "Do you TREAT patients for colorectal cancer?" were asked about MMR, UGT1A1, and KRAS testing. Though we asked respondents whether they treat patients for cancer, these questions did not specifically define the nature of the treatment rendered. Therefore, these questions could have been interpreted to include ancillary care for pain, management of sequelae of chemotherapy or surgery, or other types of care.

When examining whether a clinician ordered a specific test, we defined "ordering" a test as actually placing an order to have the test performed. We included the term "recommending", allowing for the circumstances where (1) the provider who discusses the test with the patient is different from the provider that actually orders the test, or (2) the test is not conducted, but the provider recommended the test be done. Among providers who reported they recommended screening for breast, ovarian, or colorectal cancer, but did not order or recommend the corresponding tests, we examined their rationale for not ordering or recommending OncoVue and fecal DNA. For those who reported treating breast, ovarian, or colorectal cancer, but did not order the corresponding tests, we examined their rationale for not ordering or recommending breast cancer tumor gene expression profiles, CYP2D6, UGT1A1, and KRAS. Brief explanations were provided for some tests in the survey, for example, "Have you ever ordered or recommended an OncoVue test (e.g., a multigene screening panel for patients without breast cancer) to determine a patient's breast cancer risk?"

We also asked about each provider's rationale for or against ordering or recommending each of the tests. On questions regarding the rationale for ordering or recommending BRCA or MMR testing, we classified "always" "usually," or "sometimes" responses as "yes," and "never" responses as "no." We classified respondents as referring to a genetic specialist for BRCA or MMR testing if they responded that they "always" or "usually" referred to a genetic specialist. We did not ask reasons for not ordering or recommending $B R C A$ and $M M R$ testing on the survey.

2.4. Potential Covariates. We asked about potential covariates which may affect associations between genetic testing and provider group. Demographic covariates include variables such as health care providers' age, sex, years since formal training, and whether they recommend screening or treat for breast, ovarian, and colorectal cancer. Practice covariates include variables such as number of patients seen per week, practice environment, and geographic location of health care clinic.

2.5. Data Analysis. We compared respondent self-reported practice specialty and credentials to their assigned provider group (primary care providers, naturopaths, OB-GYNs, and specialists), which was based on their specialty, designated by the Oregon licensing boards. We moved surveys of three respondents from a temporary "other" category into the provider group that better reflected their practice specialty and credentials. We excluded thirty-three surveys from further analysis because the respondents indicated that they practiced in one of the provider groups that typically do not screen or treat for breast, ovarian, or colorectal cancer (e.g., emergency medicine or anesthesiology).

We classified respondents as ordering or recommending $B R C A$ and $M M R$ tests if they reported ordering or recommending the test at least once in the 12 months prior to completing the survey. We classified respondents who had ever ordered or recommended OncoVue, fecal DNA, breast cancer tumor gene expression profile, CYP2D6, UGT1A1, and KRAS tests as ordering or recommending these tests. We used Pearson $\chi^{2}$ tests and logistic regression to assess the association between provider group and ordering or recommending cancer genetic tests, in addition to reasons why they chose to order/recommend or not order/recommend these tests.

We used logistic regression to calculate adjusted odds ratios (AOR) that compared the odds of ordering or recommending genetic testing by the provider group, using primary care providers as the referent category. Covariates were included in these models if they were significantly associated with the provider group and ordering or recommending genetic tests. We kept only covariates that changed the point estimate of the AOR by at least $10 \%$ (compared with the full model) in the final models. We did not present associations between the covariates and ordering genetic testing in this paper, as we were specifically interested in the relationship between the provider group and genetic testing. All analyses were performed using Stata version 19.0 [25]. We reported sample sizes (number of survey respondents) and percentages as unweighted numbers and estimates because the sampling methodology eliminated the need for weighting. 


\section{Results}

Of the 2,191 health care providers who received the survey, 1,242 returned the survey fully or partially completed, giving us a response rate of nearly $57 \%$, a gratifying response for a health care provider survey with the modest incentive of $\$ 10$. We defined both paper and web surveys as being fully completed if $80 \%-100 \%$ of applicable questions were answered and partially completed if 50\%-79\% of applicable questions were answered. Though partially completed surveys were used, fully completed surveys made up more than $95 \%$ of the returned surveys. After the exclusions described in the Section 2, the final sample included 1,209 respondents. Response rates were similar among all provider groups.

Table 2(a) shows selected demographic and practice characteristics of our respondents by provider group. Among those who recommended breast, ovarian, or colorectal cancer screening, specialists were much more likely to report recommending screening patients for colorectal cancer compared to breast and ovarian cancer. Similarly, specialists were more likely to report treating patients for colorectal cancer compared to breast and ovarian cancer. About onethird of naturopaths reported that they treat patients for breast, ovarian, and/or colorectal cancer, $13 \%$ of primary care providers and $16 \%$ of OB-GYNs reported that they treat patients for breast cancer, and 13\% of primary care providers reported that they treat patients for colorectal cancer. Table 2(b) outlines providers confidence in their knowledge of medical genetics by provider group. OB-GYNs had the highest level of confidence in their knowledge of breast and ovarian cancer genetics and specialists had the highest level of confidence in their knowledge of colorectal cancer genetics. Table 2(c) shows the respondent referral to a genetic specialist when they suspect a $B R C A$ or $M M R$ mutation by provider group. OB-GYNs and specialists had higher proportions who reported referring to genetic specialists for $B R C A$ or $M M R$ testing compared to naturopaths and primary care providers.

Among health care providers who report they recommend screening for breast and ovarian cancer, almost 3\% reported they had ordered or recommended OncoVue at least once, and among clinicians who report recommending screening for colorectal cancer, $4 \%$ had, at least once, ordered or recommended fecal DNA screening. Among health care providers who treat breast and ovarian cancer, $28 \%$ had ordered or recommended a breast cancer tumor gene expression profile test, while nearly $9 \%$ had ordered or recommended CYP2D6 testing. Among clinicians who treat colorectal cancer, $20 \%$ and almost $4 \%$ had ordered or recommended KRAS and UGT1A1 testing respectively.

Table 3 outlines clinician likelihood to report ordering or recommending BRCA or MMR tests in the past 12 months, by provider group. OB-GYNs were more than twice as likely to order or recommend $B R C A$ testing in the 12 months prior to completing the survey for patients without breast and ovarian cancer than primary care providers. There were no statistically significant differences between provider groups in patterns of ordering or recommending $M M R$ testing for any patients or $B R C A$ testing for patients with cancer.
The covariates that were included in the final models are described in the footnotes of Table 3.

The reason most often reported for not ordering an OncoVue, fecal DNA, breast cancer tumor gene expression profile, CYP2D6, UGT1A1, or KRAS test was lack of familiarity with the genetic test. About $10 \%$ of health care providers reported that cost or insurance noncoverage was a reason for not ordering or recommending OncoVue and fecal DNA testing. In addition, $17 \%$ and $20 \%$ of providers reported that practice guidelines did not include OncoVue and fecal DNA testing, respectively. Over one-third of health care providers reported not ordering or recommending CYP2D6, UGT1A1, and KRAS testing because these tests were not relevant to their patients (Table 4).

A majority of clinicians who reported ordering or recommending BRCA testing did so for the following reasons: the patient met practice guidelines $(82 \%-86 \%)$, to guide future screening decisions $(75 \%-80 \%)$, to guide prophylactic management decisions $(76 \%-80 \%)$, and because their patient requested the test $(79 \%-81 \%)$. Clinicians gave the same reasons for ordering or recommending $M M R$ testing, although the frequencies for each reason were lower than for $B R C A$ testing (between $40 \%-73 \%$ ) (Table 5).

We chose not to report reasons for ordering or recommending OncoVue and fecal DNA tests (that could be used in population-based screening for specific cancers) or breast cancer tumor gene expression profiles, CYP2D6, UGT1A1, and KRAS tests (that could be used to guide cancer treatment decisions), because the samples were too small to be reliable.

\section{Discussion}

There is a paucity of peer-reviewed studies assessing the clinical knowledge and use of the eight tests we investigated. Of all of the tests, BRCA has been the most studied, yet it remains underutilized. Indeed, our study suggests the likely underuse of certain tests (e.g., BRCA and $M M R$ ), which are recommended for risk stratification in people at high risk for breast, ovarian, and colorectal cancers. It also highlights important barriers to appropriate testing, such as lack of confidence in genetics knowledge and lack of familiarity with recommended genetic tests (e.g., KRAS testing when deciding whether to treat a patient with cetuximab). Additionally, our study suggests the appropriately low use of tests where there are either guidelines recommending against use, guidelines stating that there is insufficient information to recommend for or against use, no guidelines, or conflicting guidelines (e.g., OncoVue, fecal DNA, breast cancer tumor gene expression profiles, CYP2D6, and UGTA1).

The most common reason offered by clinicians for ordering or recommending $B R C A$ and $M M R$ was that the patient met practice guidelines, indicating that many providers are aware of national recommendations regarding genetic testing and consider these recommendations in making decisions about testing. Still, in settings where testing would be recommended by multiple national organizations, a sizable portion of clinicians make no reference to practice guidelines as a basis for ordering or recommending $B R C A$ or $M M R$ testing, suggesting that substantial gaps in awareness remain. 
Table 2: Summary data from the 2010 Oregon Health Care Provider Survey, by provider group.

(a) Demographic and practice characteristics ${ }^{\mathrm{a}} \mathrm{b}$.

\begin{tabular}{|c|c|c|c|c|}
\hline & $\begin{array}{c}\text { PCPs }^{\mathrm{c}} \\
n(\text { column \% })^{\mathrm{d}} \\
(95 \% \mathrm{CI})^{\mathrm{e}} \\
\end{array}$ & $\begin{array}{l}\text { Naturopaths } \\
n(\text { column \% })^{\mathrm{d}} \\
(95 \% \mathrm{CI})^{\mathrm{e}}\end{array}$ & $\begin{array}{c}\text { OB-GYNs } \\
n(\text { column \% })^{\mathrm{d}} \\
(95 \% \mathrm{CI})^{\mathrm{e}}\end{array}$ & $\begin{array}{c}\text { Specialists }^{\mathrm{f}} \\
n(\text { column \% })^{\mathrm{d}} \\
(95 \% \mathrm{CI})^{\mathrm{e}}\end{array}$ \\
\hline \multirow{2}{*}{ Total } & $363(30.0 \%)$ & $216(17.9 \%)$ & $333(27.5 \%)$ & $297(24.6 \%)$ \\
\hline & $(27.5 \%-32.7 \%)$ & $(15.8 \%-20.1 \%)$ & $(25.1 \%-30.1 \%)$ & $(22.2 \%-27.1 \%)$ \\
\hline \multirow{2}{*}{ Mean age (years) } & 357 (48.0 yrs) & 211 (43.5 yrs) & 329 (47.8 yrs) & 288 (47.6 yrs) \\
\hline & $(26 \text { yrs-76 yrs })^{g}$ & $(28 \text { yrs- }-70 \text { yrs })^{g}$ & $(27 \mathrm{yrs}-80 \mathrm{yrs})^{\mathrm{g}}$ & $(27 \mathrm{yrs}-79 \mathrm{yrs})^{\mathrm{g}}$ \\
\hline \multicolumn{5}{|c|}{ Number of patients seen per week } \\
\hline \multirow{2}{*}{$<50$} & $104(28.8 \%)$ & $185(86.4 \%)$ & $103(31.0 \%)$ & $127(43.3 \%)$ \\
\hline & $(24.4 \%-33.8 \%)$ & $(81.2 \%-90.4 \%)$ & $(26.3 \%-36.2 \%)$ & $(37.8 \%-49.1 \%)$ \\
\hline \multirow{2}{*}{$50-75$} & $129(35.7 \%)$ & $25(11.7 \%)$ & $126(38.0 \%)$ & $121(41.3 \%)$ \\
\hline & $(31.0 \%-40.9 \%)$ & $(8.0 \%-16.7 \%)$ & $(32.9 \%-43.3 \%)$ & $(35.8 \%-47.0 \%)$ \\
\hline \multirow{2}{*}{$>75$} & $127(35.5 \%)$ & $4(1.9 \%)$ & $103(31.0 \%)$ & $45(15.4 \%)$ \\
\hline & $(30.5 \%-40.4 \%)$ & $(0.7 \%-4.9 \%)$ & $(26.3 \%-36.2 \%)$ & $(11.7 \%-20.0 \%)$ \\
\hline \multirow{2}{*}{$\begin{array}{l}\text { Recommend } \mathrm{BOC}^{\mathrm{h}} \\
\text { screening to patients w/o } \\
\text { cancer }\end{array}$} & $394(97.5 \%)$ & $196(92.0 \%)$ & $326(98.5 \%)$ & $187(63.6 \%)$ \\
\hline & $(95.2 \%-98.7 \%)$ & $(87.5 \%-95.0 \%)$ & $(96.4 \%-99.4 \%)$ & $(57.9 \%-68.9 \%)$ \\
\hline \multirow{2}{*}{$\begin{array}{l}\text { Recommend CRC } \mathrm{C}^{\mathrm{i}} \\
\text { screening to patients w/o } \\
\text { cancer }\end{array}$} & $355(98.3 \%)$ & $204(95.8 \%)$ & $316(94.9 \%)$ & $275(93.5 \%)$ \\
\hline & $(96.4 \%-99.3 \%)$ & $(92.1 \%-97.8 \%)$ & $(91.9 \%-96.8 \%)$ & $(90.1 \%-95.8 \%)$ \\
\hline \multirow{2}{*}{ Treat patients for $\mathrm{BOC}^{\mathrm{h}}$} & $47(13.1 \%)$ & $79(36.9 \%)$ & $53(16.1 \%)$ & $172(58.3 \%)$ \\
\hline & $(10.0 \%-17.0 \%)$ & $(30.7 \%-43.6 \%)$ & $(12.5 \%-20.4 \%)$ & $(52.6 \%-63.8 \%)$ \\
\hline \multirow{2}{*}{ Treat patients for $\mathrm{CRC}^{\mathrm{i}}$} & $48(13.3 \%)$ & $63(29.4 \%)$ & \multirow{2}{*}{0} & $241(81.1 \%)$ \\
\hline & $(10.1 \%-17.2 \%)$ & $(23.7 \%-35.9 \%)$ & & $(76.3 \%-85.2 \%)$ \\
\hline \multicolumn{5}{|c|}{$\begin{array}{l}\text { a Category totals may be less than the total number of respondents, due to missing values. } \\
{ }^{b} \text { Bolded estimates indicate significant findings. } \\
{ }^{c} \text { PCPs: primary care providers which include family physicians, internal medicine physicians, primary care n } \\
\text { assistants. } \\
{ }^{d} \text { The column \% reflects the percent responding within each practice category. } \\
{ }^{\text {e} C I: ~ c o n f i d e n c e ~ i n t e r v a l . ~} \\
{ }^{f} \text { Specialists consisted of surgeons, colorectal surgeons, general surgeons, gastroenterologists, oncologists, and } \\
{ }^{\text {g }} \text { Range in years. } \\
{ }^{h} \text { BOC: breast and ovarian cancer. } \\
{ }^{i} \text { CRC: colorectal cancer. }\end{array}$} \\
\hline & $\begin{array}{c}\text { PCPs }^{\mathrm{c}} \\
n(\text { column \% })^{\mathrm{d}} \\
(95 \% \mathrm{CI})^{\mathrm{e}} \\
\end{array}$ & $\begin{array}{c}\text { Naturopaths } \\
n(\text { column \% })^{\mathrm{d}} \\
(95 \% \mathrm{CI})^{\mathrm{e}} \\
\end{array}$ & $\begin{array}{c}\text { OB-GYNs } \\
n(\text { column \% })^{\mathrm{d}} \\
(95 \% \mathrm{CI})^{\mathrm{e}} \\
\end{array}$ & $\begin{array}{c}\text { Specialists }^{\mathrm{f}} \\
n(\text { column \% })^{\mathrm{d}} \\
(95 \% \mathrm{CI})^{\mathrm{e}} \\
\end{array}$ \\
\hline \multicolumn{5}{|c|}{ Confidence in personal knowledge of $\mathrm{BOC}^{\mathrm{g}}$ genetics } \\
\hline \multirow{2}{*}{ Not at all } & $111(30.6 \%)$ & $92(42.6 \%)$ & $23(6.9 \%)$ & $87(30.0 \%)$ \\
\hline & $(26.1 \%-35.5 \%)$ & $(36.2 \%-49.3 \%)$ & $(4.6 \%-10.2 \%)$ & $(25.0 \%-35.5 \%)$ \\
\hline \multirow{2}{*}{ Somewhat } & $188(51.8 \%)$ & $90(41.7 \%)$ & $132(39.6 \%)$ & $115(39.7 \%)$ \\
\hline & $(46.6 \%-56.9 \%)$ & $(35.3 \%-48.4 \%)$ & $(34.5 \%-45.0 \%)$ & $(34.2 \%-45.4 \%)$ \\
\hline \multirow{2}{*}{ Moderately/very } & $64(17.6 \%)$ & $34(15.7 \%)$ & $178(53.5 \%)$ & $88(30.3 \%)$ \\
\hline & $(14.1 \%-21.9 \%)$ & $(11.5 \%-21.2 \%)$ & $(48.1 \%-58.8 \%)$ & $(25.3 \%-36.0 \%)$ \\
\hline
\end{tabular}


(b) Continued.

\begin{tabular}{|c|c|c|c|c|}
\hline & $\begin{array}{c}\text { PCPs }^{\mathrm{c}} \\
n(\text { column \% })^{\mathrm{d}} \\
(95 \% \mathrm{CI})^{\mathrm{e}}\end{array}$ & $\begin{array}{c}\text { Naturopaths } \\
n(\text { column \% })^{\mathrm{d}} \\
(95 \% \mathrm{CI})^{\mathrm{e}}\end{array}$ & $\begin{array}{c}\text { OB-GYNs } \\
n(\text { column \% })^{\mathrm{d}} \\
(95 \% \mathrm{CI})^{\mathrm{e}}\end{array}$ & $\begin{array}{c}\text { Specialists }^{\mathrm{f}} \\
n(\text { column \% })^{\mathrm{d}} \\
(95 \% \mathrm{CI})^{\mathrm{e}}\end{array}$ \\
\hline \multicolumn{5}{|c|}{ Confidence in personal knowledge of $\mathrm{CRC}^{\mathrm{h}}$ genetics } \\
\hline \multirow{2}{*}{ Not at all } & $110(30.5 \%)$ & $114(52.8 \%)$ & $77(23.2 \%)$ & $43(11.3 \%)$ \\
\hline & $(25.9-35.4)$ & $(46.1-59.4)$ & $(19.0-28.0)$ & $(8.1-15.5)$ \\
\hline \multirow{2}{*}{ Somewhat } & $190(52.6 \%)$ & $81(37.5 \%)$ & $176(53.0 \%)$ & $105(36.0 \%)$ \\
\hline & $(47.5 \%-57.7 \%)$ & $(31.3 \%-44.2 \%)$ & $(47.6 \%-58.3 \%)$ & $(30.7 \%-41.6 \%)$ \\
\hline \multirow{2}{*}{ Moderately/very } & $61(16.9 \%)$ & $21(9.7 \%)$ & $79(23.8 \%)$ & $154(52.7 \%)$ \\
\hline & $(13.4 \%-21.1 \%)$ & $(6.4-14.5)$ & $(19.5-28.7)$ & $(47.0-58.4)$ \\
\hline
\end{tabular}

${ }^{a}$ Category totals may be less than the total number of respondents, due to missing values.

${ }^{b}$ Bolded estimates indicate significant findings.

${ }^{\mathrm{C}}$ PCPs: primary care providers which include family physicians, internal medicine physicians, primary care nurse practitioners, and primary care physician assistants.

${ }^{\mathrm{d}}$ The column $\%$ reflects the percent responding within each practice category.

${ }^{\mathrm{e}} \mathrm{CI}$ : confidence interval.

${ }^{\mathrm{f}}$ Specialists consisted of surgeons, colorectal surgeons, general surgeons, gastroenterologists, oncologists, and gynecologic oncologists. gBC: breast and ovarian cancer.

${ }^{\mathrm{h}} \mathrm{CRC}$ : colorectal cancer.

(c) Referral of patients to a genetic specialist $\mathrm{t}^{\mathrm{a}} \mathrm{b}$.

\begin{tabular}{|c|c|c|c|c|}
\hline & $\begin{array}{c}\mathrm{PCPs}^{\mathrm{c}} \\
n(\text { column \% })^{\mathrm{d}} \\
(95 \% \mathrm{CI})^{\mathrm{e}}\end{array}$ & $\begin{array}{c}\text { Naturopaths } \\
n(\text { column \% })^{\mathrm{d}} \\
(95 \% \mathrm{CI})^{\mathrm{e}}\end{array}$ & $\begin{array}{c}\text { OB-GYNs } \\
n \begin{array}{c}(\text { column \% })^{\mathrm{d}} \\
(95 \% \mathrm{CI})^{\mathrm{e}}\end{array}\end{array}$ & $\begin{array}{c}\text { Specialists }^{\mathrm{f}} \\
n(\text { column \% })^{\mathrm{d}} \\
(95 \% \mathrm{CI})^{\mathrm{e}}\end{array}$ \\
\hline \multirow{2}{*}{$\begin{array}{l}\text { Referg }^{g} \text { patients w/o cancer to a } \\
\text { genetic specialist for BRCA testing }\end{array}$} & $111(67.7 \%)$ & $27(50.0 \%)$ & $225(87.5 \%)$ & $82(75.9 \%)$ \\
\hline & $(60.1 \%-74.4 \%)$ & $(36.9 \%-63.1 \%)$ & $(82.9 \%-91.1 \%)$ & $(67.0 \%-83.1 \%)$ \\
\hline \multirow{2}{*}{$\begin{array}{l}\text { Referg patients w/cancer to a genetic } \\
\text { specialist for } B R C A \text { testing }\end{array}$} & $19(55.9 \%)$ & $25(53.2 \%)$ & $40(87.0 \%)$ & $121(75.6 \%)$ \\
\hline & $(39.1 \%-71.5 \%)$ & $(39.0 \%-66.9 \%)$ & $(73.8 \%-94.0 \%)$ & $(68.3 \%-81.7 \%)$ \\
\hline \multirow{2}{*}{$\begin{array}{l}\text { Refer }^{\mathrm{g}} \text { patients w/o cancer to a } \\
\text { genetic specialist for } M M R \text { testing }\end{array}$} & $30(56.6 \%)$ & \multirow{2}{*}{$\mathrm{NA}^{\mathrm{h}}$} & $105(91.3 \%)$ & $122(77.2 \%)$ \\
\hline & $(43.0 \%-69.2 \%)$ & & $(84.5 \%-95.3 \%)$ & $(70.0 \%-83.1 \%)$ \\
\hline \multirow{2}{*}{$\begin{array}{l}\text { Referg patients w/cancer to a genetic } \\
\text { specialist for } M M R \text { testing }\end{array}$} & \multirow{2}{*}{$\mathrm{NA}^{\mathrm{h}}$} & \multirow{2}{*}{$\mathrm{NA}^{\mathrm{h}}$} & $131(81.9 \%)$ & $138(78.0 \%)$ \\
\hline & & & $(75.1 \%-87.1 \%)$ & $(71.2 \%-83.5 \%)$ \\
\hline
\end{tabular}

${ }^{a}$ Category totals may be less than the total number of respondents, due to missing values.

${ }^{b}$ Bolded estimates indicate significant findings.

${ }^{\mathrm{C}}$ PCPs: primary care providers which include family physicians, internal medicine physicians, primary care nurse practitioners, and primary care physician assistants.

${ }^{\mathrm{d}}$ The column $\%$ reflects the percent responding within each practice category.

${ }^{\mathrm{e}} \mathrm{CI}$ : confidence interval.

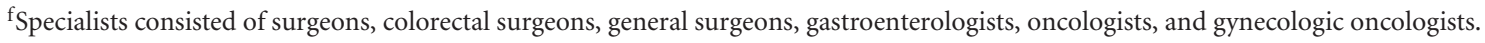

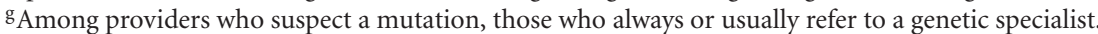

${ }^{\mathrm{h}}$ Unable to report estimates due to small cell size.

It is also worth noting that many providers reported ordering or recommending $B R C A$ and $M M R$ testing in response to requests from patients. A 2003 study assessing the impact of a pilot direct-to-consumer marketing campaign for BRCA testing in Atlanta, Denver, Raleigh-Durham, and Seattle found that providers perceived an increase in patient awareness of testing, noted an increase in patient requests for testing, and ordered more BRCA tests, but there was no change in rate of referral to genetic specialists [26, 27]. Such referrals allow patients considered to be at high risk to receive guidance from a health professional well grounded in cancer genetics about what tests would be most appropriate, as well as pre- and post-test counseling $[8,14,28]$. Providers who do not specialize in genetics would seem to be important sources of such referrals. However, we found that one-third to one-half of primary care and naturopathic providers in our sample did not make such referrals, even when they suspected patients were at an increased risk for serious hereditary cancer syndromes.

Our finding that providers are using several genetic tests for which there are no practice guidelines highlights the need for further evaluation to determine the clinical usefulness and appropriate role of these genetic tests, including several addressed in our survey. There is some evidence that gene expression profiling tests (e.g., Oncotype DX, MammaPrint, and $\mathrm{H} / \mathrm{I}$ ratio) may help estimate risk of recurrence and guide 
TABLE 3: Likelihood that clinicians reported ordering or recommending specific cancer genomic test in the past 12 months, by provider group.

\begin{tabular}{|c|c|c|c|c|c|}
\hline & $\begin{array}{c}\text { Total } \\
\text { clinicians }\end{array}$ & $\begin{array}{c}\text { PCPs }^{\mathrm{b}} \\
n(\text { column \% })^{\mathrm{c}} \\
\text { adjusted OR }^{\mathrm{d}} \\
(95 \% \mathrm{CI})^{\mathrm{e}} \\
\end{array}$ & $\begin{array}{c}\text { Naturopaths } \\
n(\text { column \% } \%)^{\mathrm{c}} \\
\text { adjusted OR }^{\mathrm{d}} \\
(95 \% \mathrm{CI})^{\mathrm{e}}\end{array}$ & $\begin{array}{c}\text { OB-GYNs } \\
n(\text { column \% } \%)^{\mathrm{c}} \\
\text { adjusted OR }^{\mathrm{d}} \\
(95 \% \mathrm{CI})^{\mathrm{e}}\end{array}$ & $\begin{array}{c}\text { Specialists }^{\mathrm{f}} \\
n \text { (column \%) }^{\mathrm{c}} \\
\text { adjusted OR }^{\mathrm{d}} \\
(95 \% \mathrm{CI})^{\mathrm{e}}\end{array}$ \\
\hline $\begin{array}{l}B R C A \text { for patients } \\
\text { without } \mathrm{BC}^{\mathrm{g}} \text { or } \mathrm{OC}^{\mathrm{h}, \mathrm{i}, \mathrm{j}}\end{array}$ & $176(62.6 \%)$ & $\begin{array}{c}51(53.7 \%) \\
1.0 \text { (referent) }\end{array}$ & $\begin{array}{c}14(36.8 \%) \\
0.8(0.3-1.9)\end{array}$ & $\begin{array}{l}75(77.3 \%) \\
2.1(1.1-4.2)\end{array}$ & $\begin{array}{c}36(70.6 \%) \\
2.1(1.0-4.7)^{\mathrm{k}}\end{array}$ \\
\hline $\begin{array}{l}B R C A \text { for patients with } \\
\mathrm{BC}^{\mathrm{g}} \text { or } \mathrm{OC}^{\mathrm{h}, \mathrm{i}, \mathrm{l}}\end{array}$ & $91(63.6 \%)$ & $\begin{array}{c}14(66.7 \%) \\
1.0 \text { (referent) }\end{array}$ & $\begin{array}{c}14(46.7 \%) \\
0.5(0.1-1.7) \\
\end{array}$ & $\begin{array}{c}11(64.7 \%) \\
0.5(0.1-2.1) \\
\end{array}$ & $\begin{array}{c}52(69.3 \%) \\
0.7(0.2-2.1)\end{array}$ \\
\hline $\begin{array}{l}\text { Lynch syndrome } \\
\text { testing }{ }^{\mathrm{m}} \text { for patients } \\
\text { without cancer }{ }^{\mathrm{n}, \mathrm{o}} \\
\end{array}$ & $68(49.6 \%)$ & $\begin{array}{c}9(25.0 \%) \\
1.0 \text { (referent) }\end{array}$ & $\begin{array}{c}4(50.0 \%) \\
3.9(0.8-20.6)\end{array}$ & $\begin{array}{c}10(50.0 \%) \\
2.6(0.8-8.8)\end{array}$ & $\begin{array}{c}45(61.6 \%) \\
2.2(0.7-7.3)\end{array}$ \\
\hline $\begin{array}{l}\text { Lynch syndrome } \\
\text { testing }^{\mathrm{m}} \text { for patients } \\
\text { with cancer }{ }^{\mathrm{n}, \mathrm{p}}\end{array}$ & $56(61.5 \%)$ & $\begin{array}{c}5(45.5 \%) \\
1.0 \text { (referent) }\end{array}$ & $\mathrm{NA}^{\mathrm{q}}$ & $\mathrm{NA}^{\mathrm{q}}$ & $\begin{array}{c}50(65.8 \%) \\
1.5(0.4-5.5)\end{array}$ \\
\hline
\end{tabular}

${ }^{a}$ Bolded estimates indicate significant findings.

${ }^{b}$ PCPs: primary care providers include family physicians, internal medicine physicians, primary care nurse practitioners, and primary care physician assistants.

${ }^{\mathrm{c}}$ The column $\%$ reflects the percent responding within each practice category.

dOR: odds ratio.

${ }^{\mathrm{e}} \mathrm{CI}$ : confidence interval.

f Specialists consisted of surgeons, colorectal surgeons, general surgeons, gastroenterologists, oncologists, and gynecologic oncologists.

gBC: breast cancer.

${ }^{\mathrm{h}} \mathrm{OC}$ : ovarian cancer.

${ }^{\mathrm{i}}$ Adjusted for number of patients seen per week and confidence in breast and ovarian cancer genetics.

${ }^{\mathrm{j} A m o n g}$ clinicians who recommend breast and ovarian screening.

${ }^{\mathrm{k}} P>0.05$.

${ }^{1}$ Among clinicians who treat breast and/or ovarian cancer.

${ }^{m}$ Specifically testing for mismatch repair (MMR) genes, which may include testing in $M C H 1, M S H 2, M S H 6$, and PMS2 genes.

${ }^{\mathrm{n}}$ Adjusted for confidence in knowledge of colorectal cancer genetics.

${ }^{\circ}$ Among clinicians who recommend colorectal cancer screening.

pAmong clinicians who treat colorectal cancer.

qUnable to report estimates due to small cell size.

treatment decisions $[12,15,28-30]$. Testing for CYP2D6 and UGT1A1 genotypes are intended to identify individuals with altered functionality in genes that effect drug metabolism. Some authors have concluded that these tests may be useful to health care providers in deciding which treatments to recommend $[13,15]$. However, evidence for the clinical utility of CYP2D6 and UGT1A1 testing is not conclusive and evidence-based national guidelines have not endorsed these tests $[7,10,12,28]$.

If a test proves to be cost effective and to lead to improved clinical outcomes, it must then be integrated into clinical practice if its potential to reduce cancer morbidity and mortality is to be realized. As we have seen in the case of BRCA testing, the best known of the eight tests in our study and included in national guidelines for a number of years, such an inclusion is an important but not sufficient part of this process. Other strategies include endorsement by medical societies, creation of decision support tools, and incorporation into current and continuing medical education [19, 21, 23, 31-33].

The lack of confidence by health care providers in their basic knowledge of cancer genetics is noteworthy and is consistent with other studies $[17,18,21-23,26]$. Because of this, there is a higher chance that tests will be ordered incorrectly or inappropriately and may be misinterpreted by a nongenetic specialist, which may significantly hamper proper risk management [34]. This suggests a need for continued training to give clinicians the necessary background to know when they should order a given genetic test, how to correctly interpret the results, and in what situations patients should be referred to a genetic specialist. The higher level of confidence in breast and ovarian cancer genetics among OB-GYNs is not surprising and is consistent with research by Trivers et al., who found that being an OB-GYN was a predictor of appropriate referral to genetic specialists [35]. Others have found that specialists, such as oncologists and OB-GYNs, are often more knowledgeable about cancer genetics and cancer risk assessment than primary care providers [26, 27, 36-38]. Low levels of confidence in personal knowledge of cancer genetics, coupled with lower rates of referral to genetics specialists for high-risk patients emphasize the need for further medical genetics training, especially among primary care providers and naturopaths.

There are several limitations to this study. Firstly, given our cross-sectional study design, we could not infer causality from our data. Secondly, the survey answers were selfreported and therefore subject to recall bias. Thirdly, differences in the time interval we used for different tests in asking clinicians whether they had ordered or recommended the tests (i.e. "ever" or "in the last twelve months") limit our ability to compare the use of all eight genetic tests amongst each other. Due to small sample sizes, we were not always able to present results for the genetic tests by provider group. Finally, we did not collect information about the nature of therapy offered by respondents who reported treating breast, ovarian, and colorectal cancer. This makes reported 
TABLE 4: Reasons why clinicians did not order or recommend various cancer genomic tests among clinicians who do not order that specific test.

\begin{tabular}{|c|c|c|c|c|c|c|}
\hline & $\begin{array}{c}\text { Not familiar with } \\
\text { test } \\
n(\%)^{\mathrm{a}} \\
(95 \% \mathrm{CI})^{\mathrm{b}}\end{array}$ & $\begin{array}{c}\text { Clinical outcomes } \\
\text { would not change } \\
n(\%)^{\mathrm{a}} \\
(95 \% \mathrm{CI})^{\mathrm{b}}\end{array}$ & $\begin{array}{c}\text { Costs too } \\
\text { much/insurance } \\
\text { will not cover it } \\
n(\%)^{\mathrm{a}} \\
(95 \% \mathrm{CI})^{\mathrm{b}}\end{array}$ & $\begin{array}{c}\text { Test not valid } \\
n(\%)^{\mathrm{a}} \\
(95 \% \mathrm{CI})^{\mathrm{b}}\end{array}$ & $\begin{array}{c}\text { Practice guidelines } \\
\text { do not include this } \\
\text { test } \\
n(\%)^{\mathrm{a}} \\
(95 \% \mathrm{CI})^{\mathrm{b}}\end{array}$ & $\begin{array}{c}\text { Test not relevant } \\
\text { to patients } \\
n(\%)^{\mathrm{a}} \\
(95 \% \mathrm{CI})^{\mathrm{b}}\end{array}$ \\
\hline \multirow{2}{*}{ OncoVue $e^{\mathrm{c}, \mathrm{d}}$} & $787(79.0 \%)$ & $24(2.4 \%)$ & $106(10.6 \%)$ & $11(1.1 \%)$ & $173(17.4 \%)$ & $75(7.5 \%)$ \\
\hline & $(76.45 \%-81.4 \%)$ & $(1.6 \%-3.6 \%)$ & $(8.9 \%-12.7 \%)$ & $(0.6 \%-2.0 \%)$ & $(15.1 \%-19.9 \%)$ & $(6.1 \%-9.3 \%)$ \\
\hline \multirow{2}{*}{ Fecal DNA ${ }^{e}$} & $783(71.8 \%)$ & $37(3.4 \%)$ & $119(10.9 \%)$ & $47(4.3 \%)$ & $216(19.8 \%)$ & $57(5.3 \%)$ \\
\hline & $(69.1 \%-74.4 \%)$ & $(2.5 \%-4.7 \%)$ & $(9.2 \%-12.9 \%)$ & $(3.3 \%-5.7 \%)$ & $(17.6 \%-22.3 \%)$ & $(4.1 \%-6.7 \%)$ \\
\hline \multirow{2}{*}{$\begin{array}{l}\text { Tumor gene } \\
\text { expression } \\
\text { profiles }^{\text {f,g }}\end{array}$} & $126(50.6 \%)$ & $14(5.6 \%)$ & $21(8.4 \%)$ & $6(2.4 \%)$ & $17(6.8 \%)$ & $21(8.4 \%)$ \\
\hline & $(44.4 \%-56.8 \%)$ & $(3.3 \%-9.3 \%)$ & $(5.6 \%-12.6 \%)$ & $(1.1 \%-5.3 \%)$ & $(4.3 \%-10.7 \%)$ & $(5.5 \%-12.6 \%)$ \\
\hline \multirow{2}{*}{ CYP2D6 } & $131(42.1 \%)$ & $10(3.2 \%)$ & $10(3.2 \%)$ & $4(1.3 \%)$ & $19(6.1 \%)$ & $96(30.9 \%)$ \\
\hline & $(36.7 \%-47.7 \%)$ & $(1.7 \%-5.9 \%)$ & $(1.7 \%-5.9 \%)$ & $(0.5 \%-3.4 \%)$ & $(3.9 \%-9.4 \%)$ & $(26.0 \%-36.3)^{\mathrm{h}}$ \\
\hline \multirow{2}{*}{$U G T 1 A 1^{\mathrm{i}}$} & $187(58.4 \%)$ & \multirow{2}{*}{$\mathrm{NA}^{\mathrm{j}}$} & $7(2.2 \%)$ & \multirow{2}{*}{$\mathrm{NA}^{\mathrm{j}}$} & $16(5.0 \%)$ & $126(39.4 \%)$ \\
\hline & $(52.9 \%-63.7 \%)$ & & $(1.0 \%-4.5 \%)$ & & $(3.1 \%-8.0 \%)$ & $(34.1 \%-44.9 \%)^{\mathrm{k}}$ \\
\hline \multirow{2}{*}{$K R A S^{\mathrm{i}}$} & $108(40.3 \%)$ & \multirow{2}{*}{$\mathrm{NA}^{\mathrm{j}}$} & $4(1.5 \%)$ & \multirow{2}{*}{$\mathrm{NA}^{\mathrm{j}}$} & $9(3.4 \%)$ & $127(47.4 \%)$ \\
\hline & $(34.6 \%-46.3 \%)$ & & $(0.6 \%-3.9 \%)$ & & $(1.7 \%-6.4 \%)$ & $(41.4 \%-53.4 \%)^{1}$ \\
\hline
\end{tabular}

${ }^{\mathrm{a}}$ The column $\%$ reflects the percent responding within each practice category.

${ }^{\mathrm{b}} \mathrm{CI}$ : confidence interval.

${ }^{c}$ OncoVue is a multigene screening panel for patients without breast cancer.

${ }^{\mathrm{d}}$ Among clinicians who recommend breast and ovarian screening to patients without breast cancer.

e Among clinicians who recommend colorectal cancer screening to patients without colorectal cancer.

${ }^{\mathrm{f}}$ Breast cancer tumor gene expression profiles include Oncotype DX, MammaPrint, and H/I ratio.

$\mathrm{g}$ Among clinicians who treat patients for breast cancer.

${ }^{\mathrm{h}}$ Test not relevant to patients because clinician does not prescribe tamoxifen to patients.

${ }^{\mathrm{i}}$ Among clinicians who treat patients for colorectal cancer.

jUnable to report estimates due to small cell size.

${ }^{\mathrm{k}}$ Test not relevant to patients because clinician does not prescribe irinotecan to patients.

${ }^{1}$ Test not relevant to patients because clinician does not prescribe anti-EGFR therapy to patients.

TABLE 5: Reasons why clinicians reported ordering specific cancer genomics tests in the past 12 months, among clinicians who ordered the genetic tests.

\begin{tabular}{|c|c|c|c|c|}
\hline & $\begin{array}{c}\text { Patient met } \\
\text { practice guidelines } \\
n(\%)^{\mathrm{a}} \\
(95 \% \mathrm{CI})^{\mathrm{b}}\end{array}$ & $\begin{array}{c}\text { Guide future } \\
\text { screening decisions } \\
n(\%)^{\mathrm{a}} \\
(95 \% \mathrm{CI})^{\mathrm{b}}\end{array}$ & $\begin{array}{c}\text { Guide prophylactic } \\
\text { treatment decisions } \\
n(\%)^{\mathrm{a}} \\
(95 \% \mathrm{CI})^{\mathrm{b}}\end{array}$ & $\begin{array}{c}\text { Patient specifically } \\
\text { requests it } \\
n(\%)^{\mathrm{a}} \\
(95 \% \mathrm{CI})^{\mathrm{b}}\end{array}$ \\
\hline \multirow{2}{*}{$\begin{array}{l}B R C A \text { for patients } \\
\text { without } \mathrm{BC}^{\mathrm{c}} \text { or } \mathrm{OC}^{\mathrm{d}, \mathrm{e}}\end{array}$} & $207(85.5 \%)$ & $192(79.7 \%)$ & $192(79.7 \%)$ & $198(81.1 \%)$ \\
\hline & $(80.5 \%-89.5 \%)$ & $(74.1 \%-84.3 \%)$ & $(74.1 \%-84.3 \%)$ & $(75.7 \%-85.6 \%)$ \\
\hline \multirow{2}{*}{$\begin{array}{l}B R C A \text { for patients with } \\
\mathrm{BC}^{\mathrm{c}} \text { or } \mathrm{OC}^{\mathrm{d}, \mathrm{f}}\end{array}$} & $100(82.0 \%)$ & $91(75.2 \%)$ & $93(76.2 \%)$ & $97(78.9 \%)$ \\
\hline & $(74.0 \%-87.9 \%)$ & $(66.6 \%-82.2 \%)$ & $(67.8 \%-83.0 \%)$ & $(70.6 \%-85.3 \%)$ \\
\hline \multirow{2}{*}{$\begin{array}{l}\text { Lynch syndrome testingg } \\
\text { for patients w/o CRC }{ }^{\text {h,i }}\end{array}$} & $72(63.7 \%)$ & $69(60.5 \%)$ & $68(58.6 \%)$ & $65(57.0 \%)$ \\
\hline & $(54.3 \%-72.2 \%)$ & $(51.2 \%-69.2 \%)$ & $(49.3 \%-67.3 \%)$ & $(47.7 \%-65.9 \%)$ \\
\hline \multirow{2}{*}{$\begin{array}{l}\text { Lynch syndrome testingg } \\
\text { for patients with CRCh,j }\end{array}$} & $50(72.5 \%)$ & $46(67.6 \%)$ & $27(40.3 \%)$ & $32(50.0 \%)$ \\
\hline & $(60.5 \%-81.9)$ & $(55.4 \%-77.9 \%)$ & $(29.0 \%-52.7 \%)^{\mathrm{k}}$ & $(37.7 \%-62.3 \%)$ \\
\hline
\end{tabular}

\footnotetext{
${ }^{a}$ The column \% reflects the percent responding within each practice category.

${ }^{\mathrm{b}} \mathrm{CI}$ : confidence interval.

${ }^{\mathrm{C} B C}$ : breast cancer.

${ }^{\mathrm{d} O C}$ : ovarian cancer.

eAmong clinicians who recommend breast and ovarian screening to patients without breast cancer.

${ }^{\mathrm{f}}$ Among clinicians who treat breast and ovarian cancer.

gSpecifically testing for mismatch repair (MMR) genes, which may include testing in MCH1, MSH2, MSH6, and PMS2 genes.

${ }^{\mathrm{h}} \mathrm{CRC}$ : colorectal cancer.

${ }^{\mathrm{i} A m o n g}$ clinicians who recommend colorectal cancer screening to patients without colorectal cancer.

${ }^{j}$ Among clinicians who treat colorectal cancer.

kFor Lynch syndrome testing for patients with cancer, the phrasing was "guide chemotherapeutic treatment decisions."
} 
differences in the frequency of treating such patients difficult to interpret. Higher rates of cancer treatment reported by naturopaths compared with primary care providers or OBGYNs may involve the perception that naturopathic efforts to improve the patient's overall health are a component of cancer treatment, a view that may not have been shared by most allopathic clinicians providing services other than surgery or chemotherapy.

\section{Conclusion}

Reducing morbidity and mortality due to breast, ovarian, and colorectal cancers is a laudable goal. Consistent use of evidence-based genetic tests could contribute to that objective, while underutilization of these tests limits their potential contribution. Perceived low levels of knowledge about relevant genetics appear to be an obstacle both to the use of these tests and to the timely referral to genetic specialists. Clinicians working in settings with higher volumes of cancer patients note higher levels of confidence in relevant knowledge of medical genetics, but even then, almost half report low confidence in their knowledge base. Education through multiple modalities is a reasonable strategy to address these perceived knowledge deficits. At this time, the appropriate role of several genetic tests is undetermined, but for some genetic tests (e.g., $B R C A$ and $M M R$ ) the cost effectiveness, efficacy in guiding preventive care and treatment, and beneficial health outcomes have been demonstrated. Continued evaluation of emerging technologies and subsequent dissemination of information about the clinical utility, interpretation, and indications for the use of such tests are necessary to ensure their integration into appropriate patient care.

\section{Acknowledgments}

The Centers for Disease Control and Prevention (CDC) Cooperative agreement no. CDC-RFAGD08-801 (Grant no. 1U38GD000061) Genomic Applications in Practice and Prevention: Translation Programs in Education, Surveillance, and Policy supported this project.

\section{Endnotes}

1. Generally, a "genetic" test assesses for the presence or effect of a single gene, while a "genomic" test assesses the presence or activity of multiple genes. In this paper, we will use the term "genetic tests" and "genetic testing" to describe both genetic and genomic tests.

2. The American College of Surgeons' Commission on Cancer has recently published new cancer program standards. These standards require that cancer risk assessment, genetic counseling, and testing services be provided to patients by a qualified genetics professional. The standards also outline the criteria for pre- and post-genetic counseling and define the training and experience of qualified genetics professionals, whom we refer to as "genetic specialists". The Cancer Program Standards 2012: Ensuring Patient-Centered Care is available at http://www .facs.org/cancer/coc/cocprogramstandards2012.pdf. See especially Standard 2.3, Risk Assessment and Genetic Counseling on pg 68.

3. Naturopathic physicians use a whole-body and minimally invasive approach with the goal of restoring the health of their patients; their model of care avoids drugs and surgery and emphasizes the use of natural agents and physical means (http://www.merriamwebster.com/medical/naturopathy).

\section{References}

[1] "American Cancer SocietyCancer Facts and Figures," 2010, http://www.cancer.org/acs/groups/content/@nho/documents/ document/acspc-024113.pdf.

[2] NCI National Cancer Institute, "Genetics of Breast and Ovarian Cancer-PDQ Summary," 2012, http://www.cancer.gov/cancertopics/pdq/genetics/breast-and-ovarian/health professional/.

[3] National Cancer Institute (NCI), "BRCA1 and BRCA2: Cancer Risk and Genetic Testing," 2009, http://www.cancer.gov/cancertopics/factsheet/Risk/BRCA.

[4] S. Chen and G. Parmigiani, "Meta-analysis of BRCA1 and BRCA2 penetrance," Journal of Clinical Oncology, vol. 25, no. 11, pp. 1329-1333, 2007.

[5] National Cancer Institute (NCI), "Genetics of Colorectal Cancer-PDQ Summary,” 2012, http://www.cancer.gov/cancertopics/pdq/genetics/colorectal/healthprofessional.

[6] W. S. B. Kohlmann, S. B. Gruber, and L. Syndrome, "GeneReviews at GeneTests: Medical Genetics Information Resource," 2004, http://www.ncbi.nlm.nih.gov/books/NBK1211/.

[7] National Comprehensive Cancer Network (NCCN), NCCN Clinical Practice Guidelines in Oncology-Colorectal Cancer Screening, 2010.

[8] National Comprehensive Cancer Network (NCCN), NCCN Clinical Practice Guidelines in Oncology-Genetic/Familial High-Risk Assessment: Breast and Ovarian, 2010.

[9] Intergenetics Incorporated, What is OncoVue, 2012, http:// www.intergenetics.com/cms/technologyandproducts/whatis oncovue.

[10] Evaluation of Genomic Applications in Practice and Prevention (EGAPP) Working Group, "Recommendations from the EGAPP working group: can UCT1A1 genotyping reduce morbidity and mortality in patients with metastatic colorectal cancer treated with irinotecan?" Genetics in Medicine, vol. 11, no. 1, pp. 15-20, 2009.

[11] Evaluation of Genomic Applications in Practice and Prevention (EGAPP), "Recommendations from the EGAPP Working Group: genetic testing strategies in newly diagnosed individuals with colorectal cancer aimed at reducing morbidity and mortality from Lynch syndrome in relatives," Genetics in Medicine, vol. 11, no. 1, pp. 35-41, 2009.

[12] Evaluation of Genomic Applications in Practice and Prevention (EGAPP), "Recommendations from the EGAPP Working Group: can tumor gene expression profiling improve outcomes in patients with breast cancer?" Genetics in Medicine, vol. 11, no. 1, pp. 66-73, 2009. 
[13] M. Tzvetkov and N. von Ahsen, "Pharmacogenetic screening for drug therapy: from single gene markers to decision making in the next generation sequencing era," Pathology, vol. 44, no. 2, pp. 166-180, 2012.

[14] U.S. Preventive Services Task Force (USPSTF), “The Guide to Clinical Preventive Services. 2010-2011,” 2010.

[15] R. G. Watson and H. L. McLeod, "Pharmacogenomic contribution to drug response," Cancer Journal, vol. 17, no. 2, pp. 80-88, 2011.

[16] D. B. White, V. L. Bonham, J. Jenkins, N. Stevens, and C. M. McBride, "Too many referrals of low-risk women for BRCA1/2 genetic services by family physicians," Cancer Epidemiology Biomarkers and Prevention, vol. 17, no. 11, pp. 2980-2986, 2008.

[17] M. J. H. Baars, L. Henneman, and L. P. Ten Kate, "Deficiency of knowledge of genetics and genetic tests among general practitioners, gynecologists, and pediatricians: a global problem," Genetics in Medicine, vol. 7, no. 9, pp. 605-610, 2005.

[18] N. Drury, J. Bethea, P. Guilbert, and N. Qureshi, "Genetics support to primary care practitioners-a demonstration project," Journal of Genetic Counseling, vol. 16, no. 5, pp. 583591, 2007.

[19] B. S. Flynn, M. E. Wood, T. Ashikaga, A. Stockdale, G. S. Dana, and S. Naud, "Primary care physicians' use of family history for cancer risk assessment," BMC Family Practice, vol. 11, article 45, 2010.

[20] J. H. Medalie, S. J. Zyzanski, M. A. Goodwin, and K. C. Stange, "Two physician styles of focusing on the family: their relation to patient outcomes and process of care," Journal of Family Practice, vol. 49, no. 3, pp. 209-215, 2000.

[21] P. W. Rose, E. Watson, P. Yudkin et al., "Referral of patients with a family history of breast/ovarian cancer-GPs' knowledge and expectations," Family Practice, vol. 18, no. 5, pp. 487490, 2001.

[22] R. D. Sifri, R. Wender, and N. Paynter, "Cancer risk assessment from family history: gaps in primary care practice," The Journal of Family Practice, vol. 51, no. 10, p. 856, 2002.

[23] S. Suther and P. Goodson, "Barriers to the provision of genetic services by primary care physicians: a systematic review of the literature," Genetics in Medicine, vol. 5, no. 2, pp. 70-76, 2003.

[24] National Comprehensive Cancer Network (NCCN), NCCN Clinical Practice Guidelines in Oncology-Colon Cancer, 2010.

[25] StataCorp, Stata statistical software for professionals, Version 19.0, College Station, Tex, USA, 2012.

[26] M. F. Myers, M. H. Chang, C. Jorgensen et al., "Genetic testing for susceptibility to breast and ovarian cancer: evaluating the impact of a direct-to-consumer marketing campaign on physicians' knowledge and practices," Genetics in Medicine, vol. 8, no. 6, pp. 361-370, 2006.

[27] Centers for Disease Control and Prevention (CDC) and P.H.G., "Genetic testing for breast and ovarian cancer susceptibility: evaluating direct-to-consumer marketing-Atlanta, Denver, Raleigh-Durham, and Seattle, 2003," Morbidity and Mortality Weekly Report, pp. 603-606, 2004.

[28] National Comprehensive Cancer Network (NCCN), NCCN Clinical Practice Guidelines in Oncology-Breast Cancer, 2010.

[29] D. Fumagalli, C. Desmedt, M. Ignatiadis et al., "Gene profiling assay and application: the predictive role in primary therapy," Journal of the National Cancer Institute Monographs, no. 43, pp. 124-127, 2011.
[30] L. J. van't Veer, H. Dai, M. J. Van de Vijver et al., "Gene expression profiling predicts clinical outcome of breast cancer," Nature, vol. 415, no. 6871, pp. 530-536, 2002.

[31] L. Acheson, "Fostering applications of genetics in primary care: what will it take?" Genetics in Medicine, vol. 5, no. 2, pp. 63-65, 2003.

[32] S. B. Haga, M. M. Carrig, J. M. O’Daniel et al., “Genomic risk profiling: attitudes and use in personal and clinical care of primary care physicians who offer risk profiling," Journal of General Internal Medicine, vol. 26, no. 8), pp. 834-840, 2011.

[33] S. E. Straus, J. Tetroe, and I. Graham, "Defining knowledge translation," Canadian Medical Association Journal, vol. 181, no. 3-4, pp. 165-168, 2009.

[34] K. L. Brierley, D. Campfield, W. Ducaine et al., "Errors in delivery of cancer genetics services: implications for practice," Connecticut Medicine, vol. 74, no. 7, pp. 413-423, 2010.

[35] K. F. Trivers, L. M. Baldwin, J. W. Miller et al., "Reported referral for genetic counseling or BRCA $1 / 2$ testing among United States physicians: a Vignette-Based Study," Cancer, vol. 117, no. 23, pp. 5334-5343, 2011.

[36] T. Doksum, B. A. Bernhardt, and N. A. Holtzman, "Does knowledge about the genetics of breast cancer differ between nongeneticist physicians who do or do not discuss or order BRCA testing?" Genetics in Medicine, vol. 5, no. 2, pp. 99-105, 2003.

[37] A. N. Freedman, L. Wideroff, L. Olson et al., "US physicians' attitudes toward genetic testing for cancer susceptibility," American Journal of Medical Genetics, vol. 120, no. 1, pp. 6371, 2003.

[38] L. Wideroff, S. T. Vadaparampil, M. H. Greene, S. Taplin, L. Olson, and A. N. Freedman, "Hereditary breast/ovarian and colorectal cancer genetics knowledge in a national sample of US physicians," Journal of Medical Genetics, vol. 42, no. 10, pp. 749-755, 2005. 


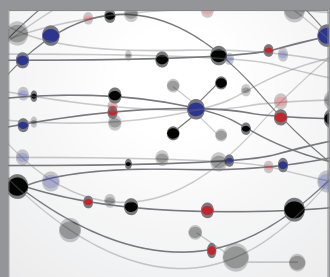

The Scientific World Journal
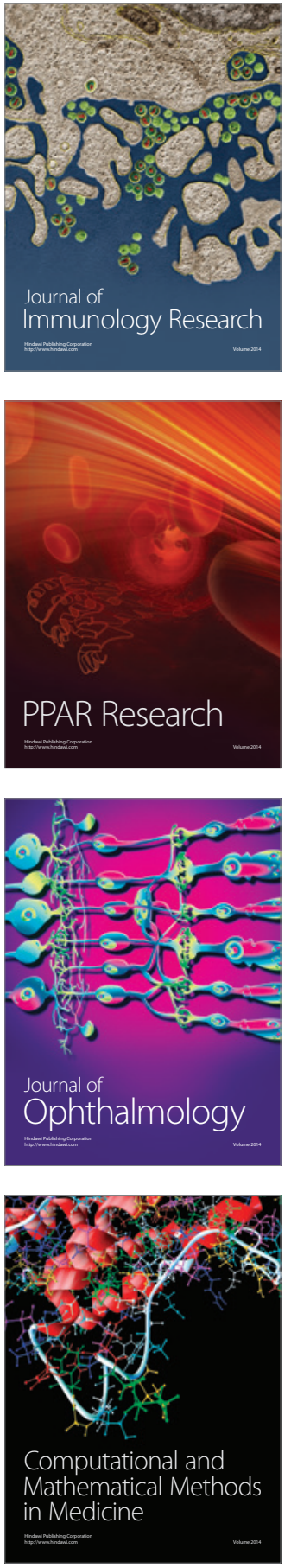

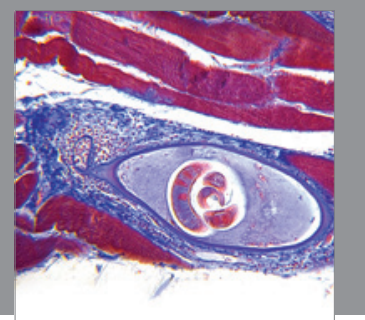

Gastroenterology

Research and Practice
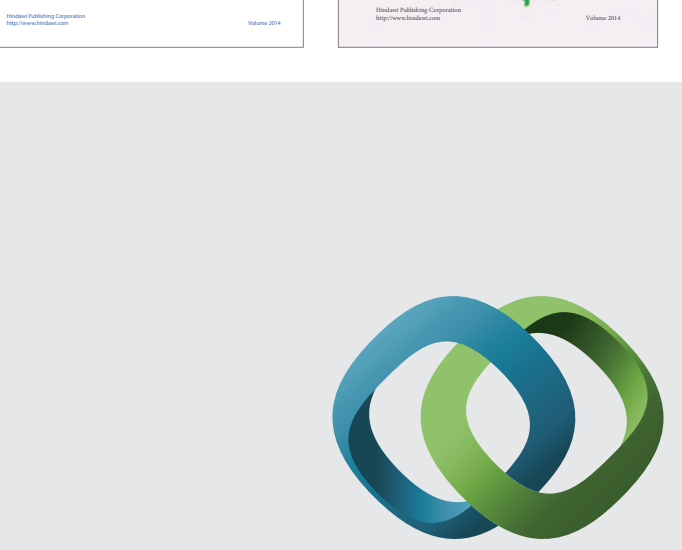

\section{Hindawi}

Submit your manuscripts at

http://www.hindawi.com
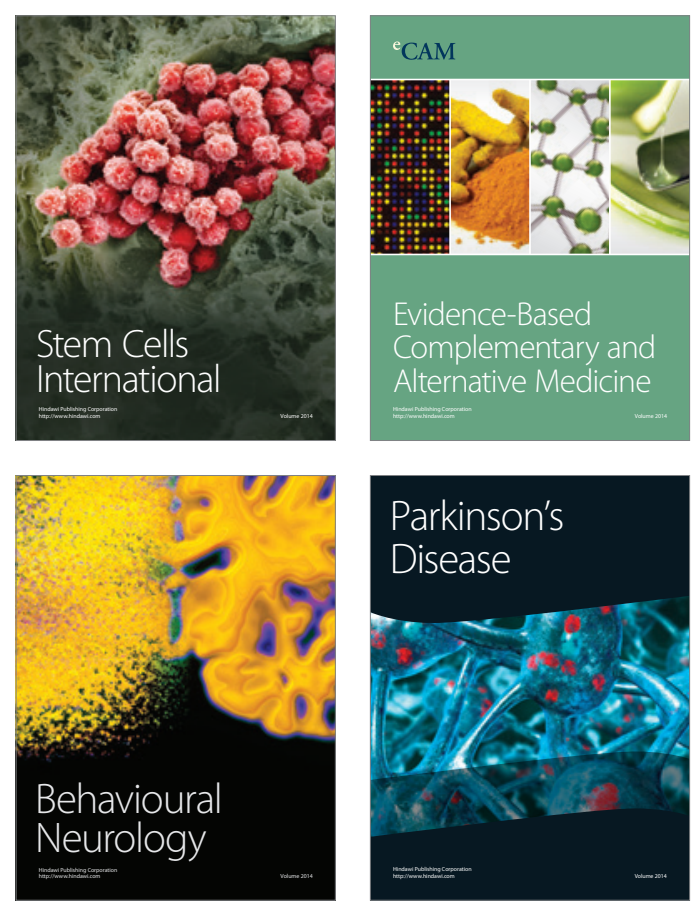

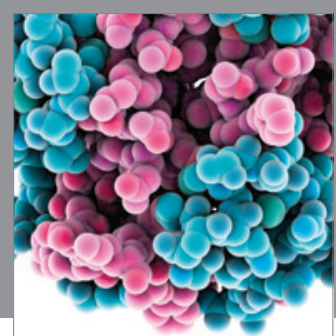

Journal of
Diabetes Research

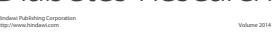

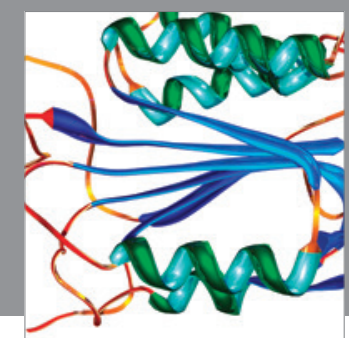

Disease Markers
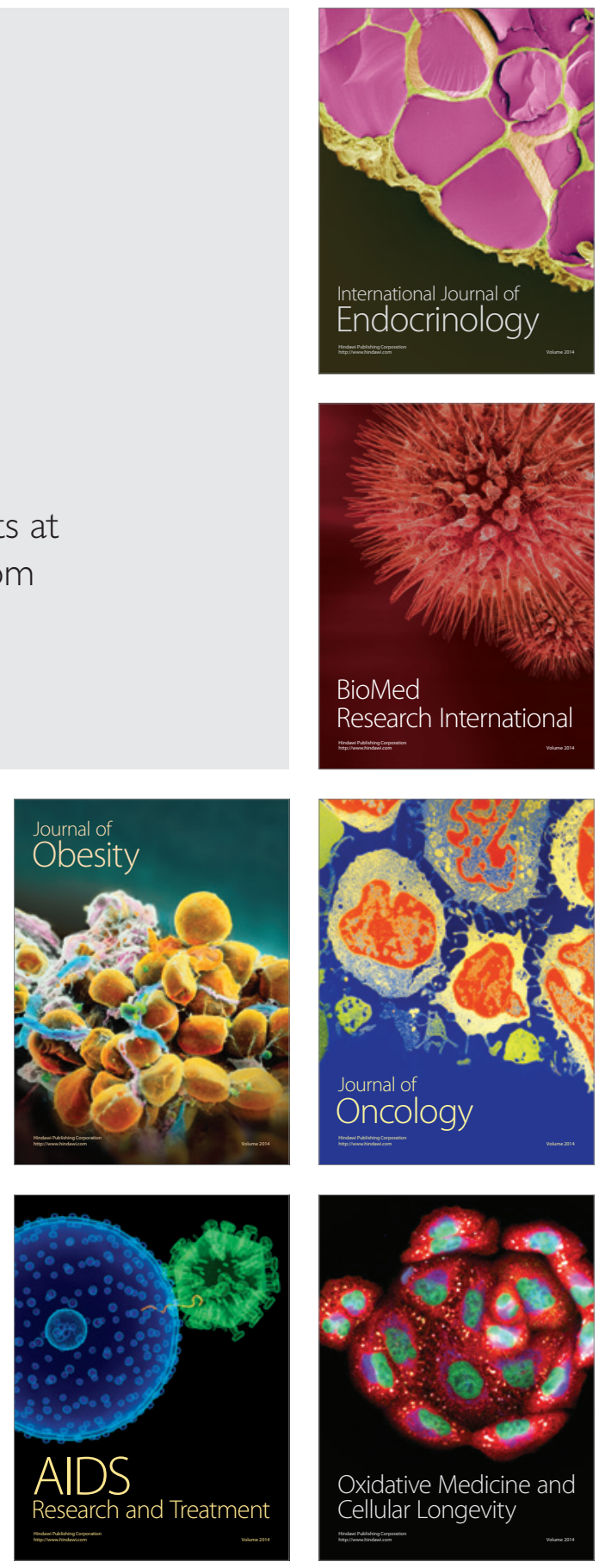